\title{
Morphological, phenological and reproductive characteristics of the invasive weed species Abutilon theophrasti Medik, as affected by various plant densities
}

\author{
MAJA ŠĆEPANOVIĆ \\ MARIJANA PLODINEC* \\ DARIO JAREŠ \\ KLARA BARIĆ \\ University of Zagreb Faculty of Agriculture, \\ Svetošimunska 25, 10000 Zagreb \\ *Postgraduate student of Phytomedicine \\ at University of Zagreb Faculty of Agriculture \\ Correspondence: \\ Maja Šćepanović \\ E-mail: mscepanovic@agr.hr
}

Key words: velvetleaf; Croatia; weed species; seed bank; intra-competition; growing degree days

Received January 24, 2017.

Revised July 15, 2018.

Accepted October 19, 2018.

\begin{abstract}
Background and purpose: Abutilon theophrasti Medik (velvetleaf) is an invasive plant well spread in Croatia as noxious weed species. The aim of this study was to provide morphological, phenological and reproductive information of velvetleaf grown under various densities: 2, 5, 10 and 20 plants $m^{-2}$.
\end{abstract}

Material and methods: The field experiment was conducted in 2014 at University of Zagreb Faculty of Agriculture as complete randomized blocks design. Throughout the vegetation morphological (hypocotyl and epicotyls length, number of leaves and branches, plant height, shoot dry weight and diameter), phenological (beginning of flowering end of flowering and first capsule formation; GDD to beginning of flowering end of flowering and first capsule formation) and reproductive (capsules plant ${ }^{-1}$, seed capsules $^{-1}$, seeds plant ${ }^{-1}$, seeds $\mathrm{m}^{-2}, 1000$ seeds weight and germinability) characteristics were measured.

Results and conclusion: Mostly all morphological and reproductive characteristics were significantly affected by plant density. Increase of velvetleaf competition from 2 to 20 plants $m^{-2}$ has reduced number of capsule and consequently almost five fold decreased seed production per plant. However, plants which have been growing at densities $>5$ plants $\mathrm{m}^{-2}$ produced in average $50 \%$ more seeds per land area than plants at the lowest density. Low germinability at harvest (2\%) and six month later (15\%) indicate on primary dormancy and possibility for longevity in soil if plants are left uncontrolled in the field. In contrast to morphological and reproductive changes, plants in high density did not showed increasing growing degree days requirements.

\section{INTRODUCTION}

butilon theophrasti is an invasive weed species that originated in A China. Velvetleaf was originally introduced to North America and Europe (Italy, German, Bulgaria and Romania) as a potential fiber crop and farmers attempted to grow it for more than a century. These early, experimental crops were probably the source of velvetleaf as a weed in row crops (1). The first data on its presence in Croatia were published in 1869 (2) but as a weed in agriculture it has been known since the 1980s, especially from the mid-1990s (3). Carey reported that the initial phases of invasion may take a substantial time, during which invading plants 
may remain at low densities for many years without being detected (4). In the last few years, this invasive weed species has spread very fast and uncontrollably (5) appearing in large numbers, sometimes with more than 200 individual plants per square meter (6). Recently, field surveys in Croatia have shown velvetleaf as the eleventh most common weed species in row crops, with a significant tendency to increase its frequency (7).

Many studies have reported decreases in crop yield due to competition from velvetleaf $(8,3,9,10)$. As a summer annual $\mathrm{C}_{3}$ species with rapid growth and high photosynthetic rates (11), canopy architecture $(12,13)$ and a moderately high relative growth rate longer in the season (12) velvetleaf has a competitive superiority of over crop and other weed species. Velvetleaf height and leaf area increase rapidly in the vegetative phase, during which most of the plant biomass is produced (9). When emerging simultaneously with corn, velvetleaf can overtake corn growth by the end of the season, developing a layer of leaves above the canopy, and therefore interfering with crop light interception (9). As few as three velvetleaf plants $\mathrm{m}^{-2} \mathrm{can}$ decrease corn yield by $91 \%$ when emerging with the crop (14) while there are no yield losses if velvetleaf emerges 25 days after corn (3). Therefore the cost of controlling this weed in the USA in the most frequently grown crops, maize and soybean, has been estimated at over 340 million US dollars (1).

The success of velvetleaf in agricultural fields has been also attributed to the longevity of seeds in the soil (15). Velvetleaf seed dormancy is primarily due to an impermeable seed coat that prevents the imbibition of water and thus prevents germination, and this is known as physical dormancy or hard-seededness (16). Due to seed longevity in the soil, the return of seeds, even from low density populations, could have long-term consequences for weed management. Specifically, long-term studies of seedbanks in soils with a history and high population of velvetleaf seeds showed that $37 \%$ of the original velvetleaf seed population was still viable after 4 years (17), while after 17 years, $15 \%$ of seeds were still viable (18). Information on weed seed production and other reproductive characteristics can influence the development of economic thresholds and weed management programs (19) although some researchers have concluded that velvetleaf seed production in crops cannot be tolerated $(9,15)$.

To establish effective, integrated weed management, an understanding of ecology and the basis for the competitiveness (morphology), phenology and biochemistry of major weed species is necessary (20). Since many plant processes are a function of the phenological stage of the plant, phenological predictions would allow more accurate estimates of the timing and effects of weed competition on crop yields in specific agronomic systems, and thus allow more specific control measures to be developed (21).

Plant competition is a process that occurs through the negative effects that individual plants have on the avail- ability of resources to neighboring individuals. Competition studies are set up to determine how different species (inter) or same species (intra) change resource availability to their neighbors, and how species respond to these changes, architecturally and physiologically, over time (22). Some researchers have shown significant morphological and reproductive velvetleaf modifications caused by inter (velvetleaf-crop) and intra (velvetleaf-velvetleaf) competition. In most cases, morphological and reproductive characteristics showed a decreasing trend when inter or intra competition was increased. In cotton, velvetleaf competition resulted in a density-dependent effect on weed biomass, ranging from 97 to $204 \mathrm{~g} \mathrm{plant}^{-1}$ dry weight (23). In corn crops, enormous reductions in velvetleaf seed production of about $99 \%$, compared to monoculture stands, was also recorded (24). Similarly, interspecific competition from soybean was also recorded as reducing velvetleaf seed production by up to $82 \%$ (25). Velvetleaf plants in intra competition also seem to reduce morphological and reproductive outputs. For example, a reduced number of seeds per plant and stem diameter were recorded when velvetleaf density was increased. With 1 to 80 plants $\mathrm{m}^{-2}$, the production of seeds was reduced on average 26.7 times, and stem diameter by $44 \%$ and $38 \%$ in a two-year experiment (10). Some research even showed that the proportion of dormant seeds produced by shaded plants could be reduced by $20 \%$ relative to seeds produced by non-shaded plants. This means that a reduction of available resources, especially light, did not only reduce the number and weight of seeds produced, but also the proportion of dormant seeds.

While considerable research has been carried out to explore the allelopathic potential of velvetleaf in Croatia $(26,6,27)$, the only study of velvetleaf morphology in Croatia was conducted by Hulina (28), but without including different plant densities. A field study was therefore conducted to provide a data set of morphological, phenological and reproductive information on velvetleaf grown under various plant densities.

\section{MATERIAL AND METHODS}

\section{Seed collection}

The velvetleaf seeds used for this study were collected randomly, from September to October 2013, from mature plants of populations which naturally infested stubble in Čazma $\left(45^{\circ} 45^{\prime} \mathrm{N}\right.$ and $\left.16^{\circ} 37^{\prime} \mathrm{E}\right)$. Seeds were hand-harvested on warm, dry days by gently shaking fully ripened seeds from mature plants. The seeds were hand-cleaned, and those that were clearly immature, damaged, or empty were eliminated. The velvetleaf seeds were stored in paper bags at room temperature until sowing time.

\section{Field experiment}

The field experiment started in spring 2014 at the Maksimir experimental station at the University of $\mathrm{Za}$ - 
greb Faculty of Agriculture (central Croatia, 45 $49^{\prime} \mathrm{N}$ and $\left.16^{\circ} 1^{\prime} \mathrm{E}\right)$. Only seeds of a visually relatively equal weight were used. Before using the seeds in the field experiment, velvetleaf germination was tested at a constant temperature of $24^{\circ} \mathrm{C}$ and photoperiods of $12: 12 \mathrm{~h}$ (light:dark). Due to low germination, the seed coat was scarified with sandpaper to break down seed coat impermeability, as suggested in Masin (29). The study site was located on sandy loam soil composed of $66.7 \%$ sand, $30 \%$ loam, $3 \%$ clay, $1.6 \%$ organic matter and $\mathrm{pH} 7.9$ on a field free of velvetleaf.

The field was disked in winter and seed bed preparation was done using a rototiller in spring before sowing. The previous crop grown on the site was oil pumpkin. One factorial experiment was carried out as a complete randomized blocks design with three replicates. Velvetleaf seeds were overplanted on 16 April 2014. at a soil depth of $2 \mathrm{~cm}$, and after emergence, thinned to four desired plant densities $\left(2,5,10\right.$ and 20 plants $\left.\mathrm{m}^{-2}\right)$. Plots were weeded regularly both by hand and with a hoe. Throughout the growing season, the following biometric determination was done: hypocotyl and epicotyl length, number of leaves, number of branches, plant height to the first flower, plant height at flowering time, plant height after flowering time, emergence date, beginning of flowering, end of flowering, first capsule formation, stem diameter and dry weight, and number of capsules per plant. At harvest, mature capsules were collected from each plant to determine the number of seeds per capsule and the number of seeds produced per plant. To minimize seed loss from fruiting, shattering paper bags were placed directly under the capsules before seed removal from the plants. Then, the velvetleaf plants were harvested by clipping at the soil surface on 25 November and dried to constant weight.

\section{Lab analysis (germination)}

The harvested capsules were stored dry at room temperature before laboratory analysis. The seeds were cleaned manually from the capsules and the total seed number and weight per plant was recorded by seed counting on a seed counter (Pfeifer). The weight of 1,000 seeds was also calculated for each velvetleaf plant, and seed moisture was measured before testing germinability.

The germination experiment was conducted twice, at harvest and six months after harvest, and was conducted in a germination chamber with constant temperature conditions of $24 / 20^{\circ} \mathrm{C}$ day/night and $12 / 12$ hours of light/ darkness. Three replicates of 100 velvetleaf seeds from each plant density plot were placed on filter paper saturated with $10 \mathrm{ml}$ of deionized water in Petri dishes sealed with Parafilm. The seeds were incubated at a constant temperature and germination was monitored daily until no further germination occurred for 10 days. The seeds were defined as germinated when they had visible radicules of at least $1 \mathrm{~mm}$.

\section{Meteorological data}

Meteorological data from the nearest weather station, Maksimir, were supplied by the Croatian Meteorological and Hydrological Service. Weather parameters consisted of monthly data for mean temperatures, precipitation and soil temperature (Table 1).

Table 1. Average monthly air and soil temperature and precipitation for Makismir, Zagreb

\begin{tabular}{|cccc|}
\hline \multirow{2}{*}{ Month } & $\begin{array}{c}\text { Air } \\
\text { Temperature }\end{array}$ & $\begin{array}{c}\text { Soil temperature, } \\
5 \mathrm{~cm}\end{array}$ & Precipitation \\
\cline { 2 - 4 } & \multicolumn{3}{c}{${ }^{\circ} \mathrm{C}$} \\
\hline April & 13.3 & 14.2 & $\mathrm{~mm}$ \\
May & 15.7 & 17.3 & 70.4 \\
June & 20.2 & 23.1 & 145 \\
July & 21.8 & 24.1 & 147 \\
August & 20.2 & 22.6 & 157.8 \\
September & 16.2 & 17.3 & 17.2 \\
\hline
\end{tabular}

Plant development is highly dependent on temperature and daily heat accumulation. Various types of temperature summations, commonly referred to as growing degree days (GDD), were used successfully to predict important phenological events for both crop and weed species (3). Therefore, growing degree days were used to estimate the beginning of emergence (Figure 1), flowering (Figure 2) and capsule formation (Figure 3) for velvetleaf. GDD was calculated as:

$$
\text { GDD }=\mathrm{T} \text { average }-\mathrm{Tb}
$$

where $\mathrm{T}$ average was the average daily temperature $\left(\mathbf{t}_{7}+\right.$ $\left.t_{14}+t_{21}\right) / 3$ and $\mathrm{Tb}$ the base temperature below which development ceases (30). The base temperature was taken from previous studies. The soil temperature was $4.5^{\circ} \mathrm{C}$ until velvetleaf emergence (31) and the air temperature was $8^{\circ} \mathrm{C}$ (32) for the period from emergence to harvest. The accumulated daily thermal units were summarised for period of interest (from sowing to the beginning of emergence, flowering and capsule formation).

\section{Data Analysis}

One-way ANOVA was used to analyze the morphological, reproductive and phenological data on velvetleaf density treatments throughout the vegetation season. Mean separation was calculated using the Least Significant Difference (LSD) values if the $F$-test was significant at $P=0.05$.

\section{RESULTS AND DISCUSSION}

\section{Velvetleaf morphology}

Environmental conditions during the study were favorable for velvetleaf growth (Table 1), and high 


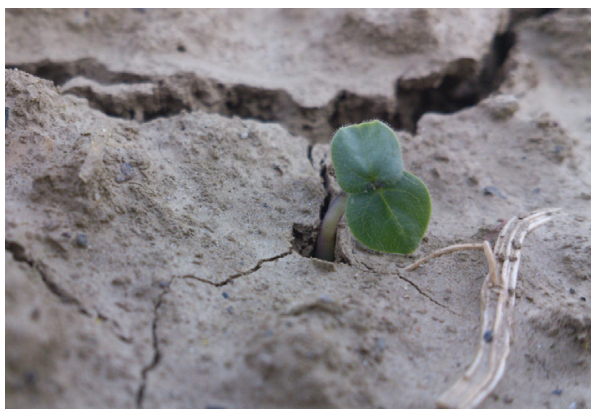

Figure 1. Cotyledons

Photos taken by Plodinec, 2014

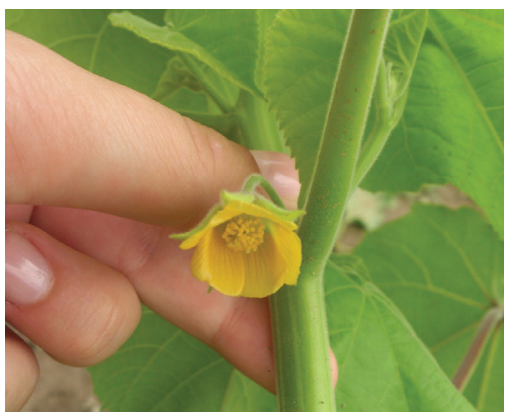

Figure 2. Flower

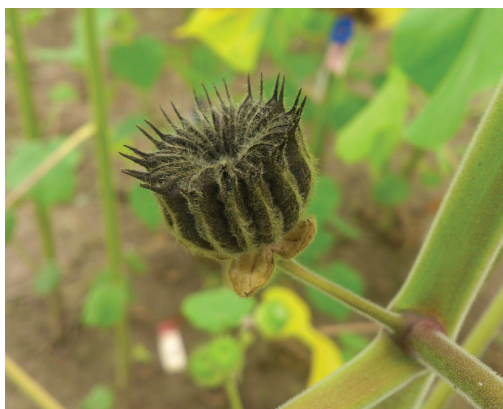

Figure 3. Capsule precipitation resulted in an average plant height of $175 \mathrm{~cm}$, as also reported for velvetleaf plants in the irrigated conditions of Mediterranean agroecosystems (24). Dry conditions are a limiting factor for velvetleaf persistence and the further spread of this weed (11).

As expected, at the beginning of the velvetleaf vegetative growth, there was no significant difference in morphological characteristics between four different plant densities (Table 2). Hypocotyl and epicotyl length averaged 1.8 and $0.7 \mathrm{~cm}$ respectively. Similarly, plant densities did not affect velvetleaf plant height before and during the flowering stage, with average plant heights of $63.6 \mathrm{~cm}$ and 80.1 respectively. The results obtained could be explained by the fact that intra-specific competition between velvetleaf plants did not influence their early growth stage. Differences in treatments were recorded at the end of the flowering stage, when all the measured morphological characteristics of velvetleaf plants decreased significantly as plant density increased (Table 2). Variability in growth between shaded and non-shaded velvetleaf plants was not significant until canopy closure, which occurred 40 days after planting (24).

The highest velvetleaf height of $211.9 \mathrm{~cm}$ was achieved at the end of flowering. The result of this investigation was similar to Steinmaus and Norris, where velvetleaf grown in full light averaged $182 \mathrm{~cm}$ (24). The plant height in the highest density $\left(20\right.$ plants $\mathrm{m}^{-2}$ ) was reduced by $24 \%$ compared to plants in the lowest density $\left(2\right.$ plant $\left.\mathrm{m}^{-2}\right)$. However, there was no significant difference in plant height between 5, 10 and 20 plants $\mathrm{m}^{-2}$. Stem height extension plays an important role in determining the exposure of leaves to light, shading competitors and elevation of reproductive structures (33). Although velvetleaf has a low shade tolerance, and stem height increases in the presence of lateral shade due to neighbors, despite a reduction in total plant biomass (34), the highest plant densities used in our research $\left(20\right.$ plant $\left.\mathrm{m}^{-2}\right)$ did not caused stem elongation. The reason may lie in the fact that velvetleaf plants were grown without competition from other plants (crops or other weeds) and therefore there was no need for stem elongation, as when velvetleaf competed with corn (10) or was laterally shaded (34). In an experiment in China, for example, velvetleaf height increased with increasing weed density from 1 to 8 plants $\mathrm{m}^{-1}$ of cotton row, while conversely, cotton height decreased due to competition from velvetleaf, especially at densities $>2$ plants $\mathrm{m}^{-1}$ (23).

The average shoot biomass at harvest time was linearly reduced as plant densities increased from 2 plants $\mathrm{m}^{-2}$ $(56.17 \mathrm{~g})$ to 20 plants $\mathrm{m}^{-2}(19.08)$ although there was no difference in plant height at densities $>50$ plants $\mathrm{m}^{-2}$ (Table 2). However, plant width, number of leaves and branches were always reduced in high densities which seemed to affect shoot biomass. Shoot diameter was significantly lower in two higher densities compared to lower plant densities. In another experiment (24), interspecific neighbors also drastically reduced velvetleaf biomass from 1,370 g (full light) to 194 (intraspecific of

Table 2. Morphological characteristics of Abutilon theophrasti in four different plant densities

\begin{tabular}{|c|c|c|c|c|c|c|c|c|c|c|}
\hline \multirow{3}{*}{$\begin{array}{l}\text { Velvetleaf } \\
\text { density } \mathrm{m}^{-2}\end{array}$} & \multicolumn{5}{|c|}{ Plant height } & \multirow{2}{*}{$\begin{array}{l}\text { Plant } \\
\text { width }\end{array}$} & \multicolumn{4}{|c|}{ Stem } \\
\hline & Hypocotil & Epicotil & $\begin{array}{c}\text { before } \\
\text { flowering }\end{array}$ & $\begin{array}{c}\text { at } \\
\text { flowering }\end{array}$ & $\begin{array}{c}\text { after } \\
\text { flowering }\end{array}$ & & Leaves & Branches & Dry weight & Diameter \\
\hline & \multicolumn{6}{|c|}{$\mathrm{cm}$} & \multicolumn{2}{|c|}{ No } & g plant $^{-1}$ & $\mathrm{~mm}$ \\
\hline 2 & 1.79 & 0.52 & 63.5 & 82.3 & 211.9 & 92.5 & 14.7 & 23.5 & 56.17 & 14.5 \\
\hline 5 & 1.81 & 0.65 & 67.5 & 83.4 & 160.1 & 64.2 & 12.3 & 27.2 & 47.53 & 13.6 \\
\hline 10 & 1.82 & 0.7 & 58.2 & 73.2 & 167.4 & 50.3 & 10.6 & 19.5 & 28.47 & 10.33 \\
\hline 20 & 1.81 & 0.73 & 64.4 & 81.4 & 160.7 & 38.4 & 9.9 & 15.6 & 19.08 & 8.3 \\
\hline LSD $(0.05)$ & ns & ns & $\mathrm{ns}$ & ns & 37.62 & 15.3 & 3.481 & 12.37 & 6.782 & 1.946 \\
\hline
\end{tabular}


Table 3 Analysis of variance for days and GDD needed for velvetleaf to flower and form first capsule

\begin{tabular}{|c|c|c|c|c|c|c|}
\hline \multirow{3}{*}{ Source of variation } & \multicolumn{6}{|c|}{ Fexp } \\
\hline & \multicolumn{3}{|c|}{ Days to } & \multicolumn{3}{|c|}{ Growing degree days to } \\
\hline & Flowering & First capsule & End of flowering & Flowering & First capsule & End of flowering \\
\hline Velvetleaf density $\mathrm{m}^{-2}$ & $3.16 \mathrm{~ns}$ & $1.61 \mathrm{~ns}$ & $2.42 \mathrm{~ns}$ & $3,05 \mathrm{~ns}$ & $1,61 \mathrm{~ns}$ & $1,98 \mathrm{~ns}$ \\
\hline
\end{tabular}

ns, non-significant

33 plants $\mathrm{m}^{-2}$ ). Other researchers also reported on the reduction of total dry matter, branches and stem diameter due to the lack of light in shaded velvetleaf plants compared to non-shaded plants $(35,36)$, or when velvetleaf was grown in a monoculture compared with velvetleaf grown with corn (37). Velvetleaf plants grown in competition with corn responded to the increased velvetleaf density by forming a slightly lower, thinner plant, with fewer branches concerted on the distal part of the stem (10).

\section{Velvetleaf phenology}

The first velvetleaf cotyledons were recorded on 29 April. The first velvetleaf plants needed 162 GDD to emerge. The estimated emergence of the Italian velvetleaf population was after an accumulation of 135 GDD (38) indicating different field emergence patterns for different populations. An additional five days (250 GDD) were needed in our study for the appearance of the first velvetleaf leaves with average dimensions of $1.8 \mathrm{~cm}$ length and $1.7 \mathrm{~cm}$ width (data not shown).

The number of accumulated growing degree days during the period from sowing velvetleaf to capsule formation was similar in all plant densities. Plant population density was not a significant source of variation in the time to the first flower and first capsule (Table 3). This result suggests that velvetleaf phenology is not influenced by plant density.

To develop the first flower on the stem, velvetleaf plants needed an accumulation of 978 degree days on average. The end of flowering time coincided with an accumulation of 1,671 degree days on average. Velvetleaf density had no effect on the number of days required for $50 \%$ of the plants to flower (37). Conversely, the authors reported that interference from corn increased the number of days from planting to the time $50 \%$ of the velvetleaf stand had flowered. Oliver stated that vegetative growth cessation coincides with initiation of flowering (39). However, in our study, stem height in all plant densities increased continuously from the first to the last flower to develop on the stem (Table 2). This may also have been due to the favorable rainfall pattern (Table 1) as reported in another study (37).

Velvetleaf plants needed on average 98 days to the first flower on the stem and a further 59 days to the end of the flowering stage, which lasted an average of 157 days (Table 3). Similarly, in northeastern North America, flower- ing occurred 12 to 13 weeks after sowing (40), while in Kashima (Japan,) velvetleaf populations needed 83 days to develop the first flowers (41).

In our study, the appearance of the first capsules on the stem averaged 107 days after sowing, and was not affected by different plant densities. The appearance of the first capsules was recorded 50 days before the end of the flowering stage (data not shown). This could be explained by the indeterminate flowering of this weed species, in which floral buds begin on the lower leaf axils and then progress up the plant during growing season (37). Similarly, a field survey in continental Croatia also reported a prolonged velvetleaf flowering stage from the beginning of June to end of September, with the first capsules appearing in mid-July (28).

\section{Reproductive characteristics}

Most velvetleaf reproductive characteristics, apart from seed capsules ${ }^{-1}$ and germinability, were significantly affected by plant density (Table 4). The absolute reduction in seeds per plant and number of capsules per plant in higher densities (5-20 plant $\mathrm{m}^{-2}$ ) compared to plants in low density $\left(2\right.$ plant $\left.\mathrm{m}^{-2}\right)$ showed the decisive influence of plant population density on the formation of reproductive organs, probably caused by changes in photosynthetic portioning, as suggested in Benvenuti's research (36). Plants growing in low density produced on average 252 capsules per plant, 68\% higher compared to the average value of plants in higher densities. Full light velvetleaf plants produced 246 and 276 mature capsules per plant respectively $(36,41)$, whereas relatively low capsule production per plant (9) in another experiment was explained by unfavorable climatic factors (low solar radiation and high precipitation) in the experiment year (42).

Although the number of capsules per velvetleaf plant varied in different density environments, the number of seeds per capsule remained constant, with an average of 33 seeds per capsule (Table 4). Decline in seed production per plant was not caused by a decrease in seeds per capsule, indicating that this trait is more or less genetically determined, as reported by other authors $(36,28,42,10)$. Mature velvetleaf capsules produced 14 locules per capsule and three seeds per locule, to produce 42 seeds per capsule, independent of the research growth conditions (10). Some authors have suggested that counting the capsules present at harvest is a reliable method of predicting total velvetleaf seed production, and this could be repli- 
Table 4 Reproductive characteristic of velveltleaf in the four different plant densities

\begin{tabular}{|c|c|c|c|c|c|c|c|c|c|}
\hline \multirow{3}{*}{$\begin{array}{c}\text { Velvetleaf } \\
\text { density } \\
\mathrm{m}^{-2}\end{array}$} & \multirow[t]{2}{*}{$\begin{array}{l}\text { Capsule } \\
\text { plant }^{-1}\end{array}$} & \multirow[t]{2}{*}{$\begin{array}{c}\text { Seeds } \\
\text { capsules }^{-1}\end{array}$} & \multirow[t]{2}{*}{$\begin{array}{c}\text { Seeds } \\
\text { plant }^{-1}\end{array}$} & \multirow[t]{2}{*}{$\begin{array}{c}\text { Seeds } \\
\mathrm{m}^{-2}\end{array}$} & \multirow[t]{2}{*}{$\begin{array}{c}1000 \text { seeds } \\
\text { weight }\end{array}$} & \multirow[t]{2}{*}{$\begin{array}{c}\text { Seed-shoot } \\
\text { biomass }\end{array}$} & \multirow[t]{2}{*}{$\begin{array}{l}\text { Barren } \\
\text { plants }\end{array}$} & \multicolumn{2}{|c|}{ Germinability } \\
\hline & & & & & & & & $\begin{array}{c}\text { At } \\
\text { harvest }\end{array}$ & $\begin{array}{c}6 \text { months } \\
\text { after }\end{array}$ \\
\hline & \multicolumn{4}{|c|}{ No } & $\mathrm{gr}$ & $\mathrm{No} \mathrm{g}^{-1}$ & $\%$ & $\%$ & \\
\hline 2 & 253 & 34 & 3737 & 7307 & 10.57 & 67.6 & 0 & 3.2 & 20 \\
\hline 5 & 98 & 34 & 2793 & 13967 & 10.09 & 58.9 & 13 & 3.0 & 10 \\
\hline 10 & 81 & 34 & 1423 & 14235 & 10.21 & 50.1 & 13 & 3.6 & 15 \\
\hline 20 & 61 & 31.8 & 781 & 15622 & 10.00 & 40.7 & 27 & 1.0 & 13 \\
\hline $\operatorname{LSD}(0,05)$ & 63,0 & ns & 918,7 & 3764 & 0,290 & 9,82 & 18,16 & ns & ns \\
\hline
\end{tabular}

cated for our study. Adjustments in reproductive outputs were therefore due to changes in the number of capsules per plant, rather than the number of seeds per capsule.

The number of seeds per plant showed a decreasing trend when density was increased, and decreased significantly with almost each plant density (Table 4). At the lowest plant density, velvetleaf produced 3,737 seeds per plant $^{-1}$ or almost five times more than seed production at higher densities. The reduction in seed production per plant was proportional to shoot reduction (dry biomass and diameter) in plants grown in higher densities compared to lower ones (Table 2). In Zanin and Sattin's experiment, the number of seeds per plant also diminished with increasing weed density, following a hyperbolic trend. Seed production per plant was 2.5 times lower in shaded velvetleaf plants compared to non-shaded plants (36). Moreover, the number of seeds per plant generally decreased as velvetleaf density increased, when mean seed production decreased from 8,652 to 3,719 per plant at 0.1 and 3.5 plants $\mathrm{m}^{-2}$ of cotton crop (43). Interspecific competition from soybean was also shown to reduce velvetleaf seed production by up to $82 \%$, compared to velvetleaf plants grown in monocultures (44).

Seed-shoot biomass ratio also decreased linearly as plant densities increased (Table 4). Plants in high stands (20 plants $\mathrm{m}^{-2}$ ) had a significantly lower seed-shoot biomass ratio compared to other intraspecific competitive conditions (2-10 plants $\mathrm{m}^{-2}$ ) where plants produced more seeds at the expense of shoot biomass. Velvetleaf plants in high intraspecific competition ( 33 plants $\mathrm{m}^{-2}$ ) also developed significantly lower seed production compared to plants grown at low intraspecific competition (1.3 plants $\mathrm{m}^{-2}$ ), because shoot biomass and seed shoot ratio were reduced (24). A significant impact of intraspecific competition on seed shoot biomass ratio and consequently on seed production was found (22). Therefore, the variation in seed-shoot biomass ratios for velvetleaf grown under various competitive conditions indicates the need to exercise caution when estimating seed production from overall biomass, as suggested by this author.

Velvetleaf seed production $\mathrm{m}^{-2}$ also increased with increasing density, although statistically lower values were recorded only at the lowest point of comparison with other plant densities. Plants growing at densities of more than 5 plants $\mathrm{m}^{-2}$ produced on average 14,608 seeds $\mathrm{m}^{-2}$, compared to 7,307 seeds $\mathrm{m}^{-2}$ at the lowest density. This $50 \%$ increase in seed production per land area was achieved despite significantly reduced numbers of seeds per plant and numbers of fertile plants (Table 4). It means that despite the reduced numbers of fertile plants and seeds produced per plant in higher densities, velvetleaf grown in intracompetition may produce enough seeds to maintain a seed bank. Abutilon theophrast $i$ is a species that is able to produce a persistent seedbank (10) since its seeds are characterized by notable longevity (15). It is well known that a fundamental principle of integrated pest management is the use of economic thresholds to support pesticide application. Information on weed seed production can influence the development of economic thresholds, since seed dispersal may be a more important consideration than yield losses associated with competition $(45,46)$. Seed return from subthreshold velvetleaf population resulted in seedling populations above the threshold in the subsequent year (15). Unfortunately, the reproductive characteristics of this weed species exclude the possibility of weed population management based on the concept of a threshold (10); the threshold level for this species is zero (47).

Several authors $(10,41)$ observed that the weight of 1,000 seeds remained constant regardless of the light availability in different density environments, but our study results showed a significantly small difference in 1,000 seeds weight in the higher density compared to the lowest one. However, plant density did not influence velvetleaf germinability, either soon after harvest or six months later. Freshly harvested velvetleaf seeds showed very low germinability in all density environments - an average of $2.7 \%$ (Table 4). It is well documented that most annual summer weed species such as velvetleaf show primary dormancy soon after harvest time, to ensure that seeds remain viable over the season and are able to germinate when conditions are appropriate. When velvetleaf hard-seededness caused by the impermeable seed coat became permeable, physical dormancy was lost and ger- 
mination could occur. This, however did not happen in our study six months after harvesting, when germinability was still low (14.5\% on average).

\section{CONCLUSIONS}

Velvetleaf plants grown in different, intraspecific plant densities showed high morphological and reproductive diversity, as reported in other research. The first significant difference in plant height between different plants densities was observed after the flowering stage. Almost all morphological parameters, such as maximum plant height and weight, shoot biomass and shoot diameter, were significantly reduced in intraspecific densities above 5 plant $\mathrm{m}^{-2}$.

Our results confirmed that the seed number per capsules was constant, regardless of plant densities. The increase in intraspecific competition from 2 to 20 plants $\mathrm{m}^{-2}$ reduced the number of velvetleaf capsules per plant and consequently decreased seed production almost fivefold per plant, while barren plants increased significantly from 0 to up to $27 \%$. However, seed production per land area increased from 7,307 seeds $\mathrm{m}^{-2}$ at the lowest, to 15,622 seeds $\mathrm{m}^{-2}$ at the highest plant densities. Low germinability at harvest $(2 \%)$ and six months later $(15 \%)$, detected in this research, indicated primary dormancy which was similar for all plant densities. The results of the present study indicate velvetleaf reproductive adaptation to produce enough seeds to maintain a seed bank at a range of different plant densities. Velvetleaf adaptation to intra competition conditions was also evident from stable phenological characteristics, where plants showed similar GDD requirements for the beginning of flowering and capsule formation at different density stands.

\section{REFERENCES}

1. SPENCER NR 1984. Velvetleaf, Abutilon theophrasti (Malvaceae), history and economic impact in the United States. Econ. Bot. 38: 40'7-416. https://doi.org/10.1007/BF02859079

2. SCHLOSSER JC AND FARKAŠ-VUKOTINOVIĆ L 1869. Flora Croatica, Zagrabiae

3. LEŠNIK M 1999. Ekološke in fitocenološke razmere tekmovalnega odnosa med plevelom baržunasti oslez (Abutilon theophrasti Med.) in poljščinami v Sloveniji in možnosti za njegovo zatiranje. Doktorska disertacija, Biotehniška fakulteta, Univerziteta v Ljubljani

4. CAREY JR 1996. The incipient Mediterranean fruit fly population in California: Implications for invasion biology. Ecology 77:16901697. https://doi.org/10.2307/2265775

5. FLEGAR Z AND NOVAK N 2005. Europski mračnjak (Abutilon theophrasti Med.). Zavod za zaštitu bilja u poljoprivredi i šumarstvu Republike Hrvatske.Ministarstvo poljoprivrede, šumarstva i vodnoga gospodarstva Republike Hrvatske, Zagreb

6. NOVAK N 2007. Alelopatski utjecaj europskog mračnjaka (Abutilon theophrasti Med.) na neke poljoprivredne kulture. Master thesis, University of Zagreb, Faculty of Agriculture

7. OSTOJIC Z 2011. The changes of the composition of weed flora in southeastern and central europe as affected by cropping practices - Croatia. In ŠARIĆ T, OSTOJIC Z, STEFANOVIC L., KACIZNSKI G, TYŠER D 2011 Herbologia 12: 8-12
8. CARDINA J, REGNIER E, SPARROW D 1995. Velvetleaf ( $A b u$ tilon theophrasti) competition and economic thresholds in conventional and no-tillage corn (Zea mays). Weed science, 43:83-87

9. SATIN M, ZANIN G, BERTI A 1992. Case history for weed competition/population ecology: velvetleaf (Abutilon theophrasti) in corn (Zea mays). Weed Technol. 6:213-219. https://doi.org/10.1017/S0890037X00034588

10. ZANIN G AND SATTIN M 1988. Threshold level and seed production of velvetleaf (Abutilon theophrasti Medikus) in maize. Weed Res. 28:347-352.

https://doi.org/10.1111/j.1365-3180.1988.tb00813.x

11. HOLT JS, BOOSE AB 2000. Potential for spread of Abutilon theophrasti in California. Weed Science 48:43-52. https://doi.org/10.1614/0043-1745(2000)048[0043:PFSOAT]2.0. $\mathrm{CO} ; 2$

12. AKEY WC, JURIK TW, DEKKER J 1990. Competition for light between velvetleaf (Abutilon theophrasti) and soybean (Glycine max). Weed Research 30:403-411. https://doi.org/10.1111/j.1365-3180.1990.tb01728.x

13. AKEY WC, JURIK TW, DEKKER J 1990. A replacement series evaluation of competition between velvetleaf (Abutilon theophrasti) and soybean (Glycine max). Weed Research 31:63-72. https://doi.org/10.1111/j.1365-3180.1991.tb01744.x

14. STERLING TM AND PUTNAM, AR 1987. Possible role of glandular trichome exudates in interference by velvetleaf (Abutilon theophrasti). Weed Science 35:308-314.

15. CARDINA J. AND NORQUAY HM 1997. Seed production and seedbank dynamics in subthreshold velvetleaf (Abutilon theophrasti) populations. Weed Science 45, 85-90

16. BASKIN CC, BASKIN, JM, LIX. 2000. Taxonomy, anatomy and evolution of physical dormancy in seeds. Plant species biology 15:139-152. https://doi.org/10.1046/j.1442-1984.2000.00034.x

17. LUESCHEN WE AND ANDERSEN RN 1980. Longevity of velvetleaf (Abutilon theophrasti) seed in soil under agricultural practices. Weeds Sci. 28:341-346

18. LUESCHEN WE, ANDERSEN RN, HOVERSTAD TR, KANNE BK. 1993. Seventeen years of cropping systems and tillage affect velvetleaf (Abutilon theophrasti) seed longevity. Weed Sci. 41:82-86. https://doi.org/10.1017/S0043174500055429

19. KHEDIR.D, ROETH FW1981. Velvetleaf (Abutilon theophrasti) seed populations in six continous-corn (Zea mays) fields. Weed Science, 29: 485-490. https://doi.org/10.1017/S0043174500040042

20. SHAW WC 1982. Integrated weed management systems technology for pest management. Weed Science 30 (suppl.): 2-12

21. ALM DM, MCGIFFEN ME, HESKETH JD 1991. Weed phenology. In T. Hodges (Ed.), Predicting crop phenology:191-218. Boca Raton, FL: CRC Press.

22. TREMMEL DC AND BAZZAZ FA 1994. How neighbor canopy architecture affects target plant performance. Ecology 74: 2114 2124. https://doi.org/10.2307/1940856

23. MAX, YANG J, WU H, JIANG W, MA Y; MA Y (2016). Growth Analysis of Cotton in Competition with Velvetleaf (Abutilon theohprasti). Weed Technology 30:123-13. https://doi.org/10.1614/ WT-D-15-00050.1

24. STEINMAUS SJ AND NORRIS RF 2002. Growth analysis and canopy architecture of velvetleaf grown under light conditions representative of irrigated Mediterranean-type agroecosystems. Weed Science 50:42-53.

https://doi.org/10.1614/0043-1745(2002)050[0042:GAACAO]2.0. $\mathrm{CO} ; 2$

25. LINDQUIST JL, MAXWELL BD, BUHLER DD, GUNSOLUS JL 1995. Velvetleaf (Abutilon theophrasti) recruitment, survival, seed production and interference in soybean (Glycine max). Weed Sci. 43:226-232

26. GALZINA N, ŠĆEPANOVIĆ M, TURK I, GORŠIĆ M 2011. Allelopathic effect of Abutilon theophrasti Med. on lettuce, carrot and red beet. Herbologia 2:125-131 
27. ŠĆEPANOVIĆ M, NOVAK N, BARIĆ K, OSTOJIĆ Z, GALZINA N, GORŠIĆC M 2007. Alleopathic effect of two weed species, Abutilon theophrasti Med. and Datura stramonium L. on germination and early growth of corn. Agronomski glasnik 6: 459-472

28. HULINA N (2000). Verbreitung und biologie von Abutilon theophrasti med. in Kroatien. Z.PFLKrankh. PflSchutz, Sonderh. 153158

29. MASIN R, LODDO S, BENVENUTI M, ZUIN C, MACCHIA M, ZANIN G 2010. Estimation of temperature and water potential thresholds for the main weed species in maize in north-central Italy. Weed Sci. 58:216-222. https://doi.org/10.1614/WS-D-09-00066.1

30. BAKER JT AND REDDY VR 2001. Temperature effects on phenological development and yield of muskmelon. Annals of Botany, 87, 605-613. https://doi.org/10.1006/anbo.2001.1381

31. MAGOSSO D. 2013. Study of germination parameters of summer weeds: transferability of AlertInf model to Croatia. Final thesis, University of Padova, Department of Agronomy, Food, Natural resources, Animals and Environment (DAFNAE).

32. GRAMING GG AND STOLTENBERG DE 2007. Leaf Appearance Base Temperature and Phyllocron for Common Grass and Broadleaf Weed Species. Weed Technology 21:249-254. https://doi.org/10.1614/WT-06-039.1

33. BERNTSON GM AND WAYNE PM 2000. Characterizing the size dependence of resource acqusition within crowded plant populations. Ecology 81: 1072-1085.

https://doi.org/10.1890/0012-9658(2000)081[1072:CTSDOR]2.0. $\mathrm{CO} ; 2$

34. HENRLY HAL AND THOMAS SC 2002. Interactive effects of lateral shade and wind on stem allometry, biomass allocation and mechanical stability in Abutilon theophrasti (Malvaceae). American Journal of Botany 89:1609-1615. https://doi.org/10.3732/ajb.89.10.1609

35. BELLO IA, OWEN M. HATTERMAN-VALENTI, HM 1995. Effect of shade on velvetleaf (Abutilon theophrasti) growth, seed production and dormancy. Weed Technology 9:452-455. https://doi.org/10.1017/S0890037X00023678

36. BENVENUTI S, MACCHIA M, STEFANI A 1994. Effects of shade on reproduction and some morphological characteristics of Abutilon theophrasti Medicus, Datura stramonium L. and Sorghum halepense L. Pers. Weed Research 34: 283-288. https://doi.org/10.1111/j.1365-3180.1994.tb01996.x

37. DEFELICE MS, WITT WW, BARRETT M 1988. Velvetleaf (Abutilon theophrasti) growth and development in conventional and no-tillage corn (Zea mays). Weed Science 36: 609-615

38. MASIN R, LODDO D, BENVENUTI S, OTTO S, ZANIN G 2012. Modeling Weed Emergence in Italian Maize Fields. Weed Science 60: 254-259. https://doi.org/10.1614/WS-D-11-00124.1

39. OLIVER LR 1979. Influence of soybean (Glycine max) planting date on velvetleaf (Abutilon theophrasti) competition. Weed Sci. 27:183-188

40. WARWICK SI AND BLACK LD 1998. The biology of Canadian weeds 90. Abutilon theophrasti, Can. J. Plant Sci. 68:1069-1085. https://doi.org/10.4141/cjps88-127

41. KUROKAWA S, SHIMIZU N, UOZUMI S, YOSHIMURA Y 2003. Intra-specific variation in morphological characteristics and growth habitat of newly and accidentally introduced velvetleaf (Abutilon theophrasti Medic.) into Japan. Weed Biology and Management 3:28-36. https://doi.org/10.1046/j.1445-6664.2003.00078.x

42. SATTO S, TATENO K, KOBAYASHI R 1994. Influence of seeding date on flowering and seed production of velvetletaf (Abutilon theophrasti Medic.) Weed Res. Jpn.39:243-248.

https://doi.org/10.3719/weed.39.243

43. BAILEY AW, ASKEW DS, DORAI-RAJ S, WILCUT WJ2003. Velvetleaf (Abutilon theophrasti) interference and seed production dynamics in cotton. Weed Science 1: 94-101. https://doi.org/10.1614/0043-1745(2003)051[0094:VATIAS]2.0. $\mathrm{CO} ; 2$

44. COBLE, HD. AND MORTENSON DA 1992. The threshold concept and its application to weed science. Weed Technology 6:191-195. https://doi.org/10.1017/S0890037X00034552

45. MAXWELL BD. AND GHERSA C 1992. The influence of weed seed dispersion versus the effect of competition on crop yield. Weed Technology 6:196-204. https://doi.org/10.1017/S0890037X00034564

46. NORRIS RF 1984. Weed thresholds in relation to long-term population dynamics. Proceedings of the Western Society of Weed Science 37 38:43 